\title{
KAKO ČUTI RIJEČ BOŽIJU
}

Sažetak

Ovaj rad je pokušaj da se ponudi put razumijevanja sadržaja Kur'ana na način slušanja više nego čitanja. Ako čitalac otvori srčani sluh i Božije Riječi pokuša čuti kao upućene upravo njemu, pronaći će bezbroj prelijepih smjernica da mijenja svoj život u pozitivnom pravcu. To će mu pomoći da sa svakim ajetom učini korak bliže Božijem zadovoljstvu. Zar to nije konačni cilj svakom muslimanu, iskreno predanom Bogu Dragome?

Ključne riječi: Božija Riječ, Božija blizina, Božije zadovoljstvo

\section{Uvod}

Prateći kontakt naših ljudi sa časnim Kur'anom, kao njima objavljenom knjigom, primjećujemo kako ona, čak i kod oni koji je često „uče“ ne mijenja bitno njihovu praksu. Razlog tome smo pokušali smjestiti u način njihovog pristupa tom Božijem uputstvu za životnu upotrebu. Očito je da naši muslimani Kur'anu ne pristupaju tako, ne zato što to ne žele, nego zato što im nedostaje konkretan obrazac kako iz Kur'ana crpiti smjernice. Za ilustraciju smo, ovaj put, ponudili način čitanja dvije sure: Muzzemmil i Muddessir, sa nadom da će ovakav pristup pomoći. Čitalac treba samo otvoriti svoje srce poruci Kur'ana.

\section{EL-MUZZEMMIL / UMOTANI (73)}

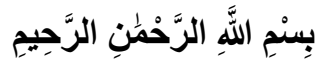

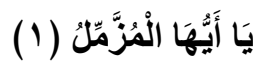

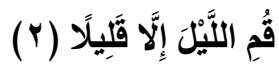

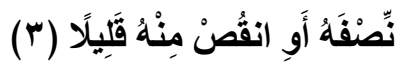

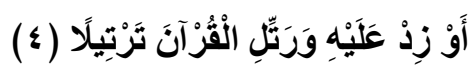

\footnotetext{
${ }^{1}$ Behram-begova medresa u Tuzli.
} 


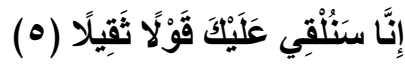

\section{U ime Allaha, Milostivog, Samilosnog ${ }^{2}$}

\section{O ti, umotani!}

\section{2. probdij noć, osim malog dijela; -}

\section{3. polovinu njezinu ili malo manje od nje;}

\section{4. ili malo više od nje, i izgovaraj Kur'an pažljivo,}

\section{Mi ćemo ti, doista, teške riječi slati.}

O ti što u svom Hirau za Istinom tragaš, strah od odgovornosti neka te ne navede da se skloniš pod plašt svog komoditeta, i tu se primiriš. ${ }^{3}$ Ako osjetiš da nemaš dovoljno snage za odgovornost nošenja emaneta Vjere, prenošenja Njegove Riječi i življenja Pravog Puta, onda dodatnu snagu potraži u ibadetu. Sedžde i duga stajanja pred Uzvišenim, u tihim noćnim satima, dok drugi spavaju, najpogodniji je oblik jačanja svog duha. Previše spavanja umrtvljuje dušu.

Ako želiš da procijeniš koliko je noćnog ibadeta potrebno baš tebi da bi snagu povećao, onda kreni od donje granice - bar jednu trećinu noći probdij ispunjavajući je različitim vidovima ibadeta: klanjajući, zikreći ili Kur'an učeći.

Kur'an uči polagano, prateći smisao njegovih ajeta i osjećajući da se obraća upravo tebi. Poneku poruku i zapiši. Posebno onu koja ti je u tim danima iznimno važna i o njoj više misli. Sve što sutra, kada svane, mogneš odmah primijeniti učini to! Ništa ne odgađaj! Neka ti to bude princip u životu!

2 Prijevodi ajeta su uglavnom preuzimani iz: Kur'an s prevodom, (preveo Besim Korkut), Sarajevo, 1989., izuzev mjesta na kojima smo smatrali da bi odgovarao drugačiji prijevod. Pri traženju alternativnog prijevoda služili smo se:

a. Kur'an s prijevodom na bosanski jezik, (preveo Esad Duraković), Sarajevo, 2004.

b. Kur'an sa prijevodom na bosanski jezik, (preveo Enes Karić), Sarajevo,1995.

c. Muhammed Asad, Poruka Kur'ana, (preveo Hilmo Ćerimović), Sarajevo, 2004.

3 Muhammed Asad, pojašnjavajući značenje pojma muzzemmil, između ostalog navodi: "Međutim, nema nikakve sumnje da, bez obzira na to kakav je lingvistički smisao obraćanja 'O, umotani', on implicira poziv na povećanje svijesti i dublje duhovne budnosti...” Poruka Kur'ana, str. 921. 
Kada osjetiš da ti ta količina više ne predstavlja poteškoću, povećavaj je do jedne polovine noći. Kada vidiš da ti ni provesti pola noći u ibadetu više nije teško, povećavaj do dvije trećine, ali dalje ne idi. Tvoje tijelo ima pravo da se odmori. Čuvaj i njegov hakk!

Nakon određenog vremena, najčešće je to jedna godina dana, osjetit ćeš kako posjeduješ dovoljno duhovne, ali i tjelesne, snage da poneseš emanet življenja i širenja Božije Riječi u okruženju, a taj emanet je itekako težak. Ko ne shvata ozbiljnost i težinu nošenja i prenošenja tog emaneta nije ni dostojan da se time bavi. Samo nemoj zaboraviti da je i nagrada adekvatna težini uloženog napora.

Sjeti se da je Uzvišeni i tvog najvećeg učitelja Muhammedpejgambera istim riječima pozvao da ustane, sa sebe skine pokrivač kojim je groznicu straha tjerao od sebe, i krene u duhovno učvršćivanje sebe i svojih ashaba. Nije se on bojao obaveze, nego je bio fasciniran veličanstvenim izgledom jednog od Božijih meleka, plemenitog Džibrila. Zaklanjao je cijeli horizont, kada mu se jednom pokazao u svom prirodnom liku. ${ }^{3}$ A kako li je tek veličanstven njegov Stvoritelj, Koji ti šalje Svoju Riječ da osvijetljen njenim nurom hodiš kroz dunjalučke tmine? Ti i oni što su uz tebe.

Razmisli o tome! Najbolje ćeš razmišljati u svojoj osami, kad noćni sati oko tebe sve umire.

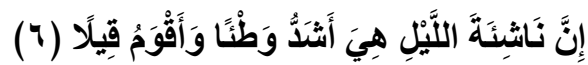

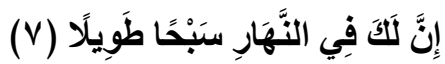

\section{6. ta ustajanje ${ }^{4}$ noću, zaista, jače djeluju i izgovara se jasnije,}

\section{7. a ti danju imaš, doista, mnogo posla.}

Noćni sati su Božija blagodat upravo zbog njihove mirnoće. Noćna vreva je zulum koji čovjek današnjice čini prema noći. Isključi se! Tu Božiju blagodat iskoristi da jasno čuješ svoje srce kad izgovara

\footnotetext{
${ }^{3}$ Vidi: Muhammed b. Ismail el-Buhari, Sahihu-l-Buhari, (preveo Hasan Škapur i grupa prevodilaca), Sarajevo, 2008, t. 1. str. 7.

${ }^{4}$ Duša (osoba) koja ustane noću iz svoje postelje radi robovanja Bogu, dž.š., naziva se na ovom mjestu naiši'a. To tvrde mnogi komentatori Kur'ana, među njima i Zamahšeri (4/638). Vidi: Kur'an sa prijevodom na bosanski jezik, (preveo Enes Karić), str. 574.
} 
veličanstvenu riječ- Allah. Zaboravi tada na svoje dnevne obaveze, na Dunjalučke zahtjeve i sve drugo. Neka je samo jedno pred tobom ime Uzvišenog, ime Allah.

Njegove riječi izgovaraj polagano i jasno. Poruke urezuj duboko u dušu. Moli Rabba svoga da te vodi. Kroz Dunjaluk, do Sebe. Noć neka bude svjedok tvoje iskrenosti.

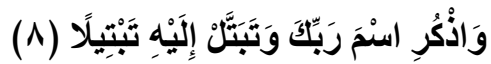

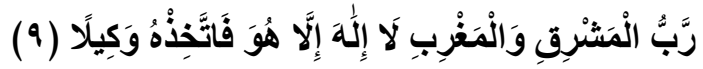
posveti!

8. I spominji ime Gospodara svoga i Njemu se potpuno

9. On je Gospodar istoka i zapada, nema boga osim Njega, Njega uzmi za zaštitnika!

Dok noć bude svjedočila o tvojoj iskrenoj predanosti i posvećenosti Voljenom Rabbu, ti Ga moli da te štiti i čuva, da te brani i o tebi se brine, da bude Vekil tvoj. Ti drugog Zaštitnika nemaš. Ti boljeg Prijatelja nemaš.

Dok Mu budeš dove upućivao, On će ti uzvratiti neprocjenjivim darom, nezamjenjivim nimetom koji se saburom zove. A sabura ti treba, kud god da kreneš. Najviše onda kada te nevjernici počnu svojim otrovnim riječima, tim pakosnim žaokama, bosti, gdje god i kad god stignu. Sabur će ti pomoći da njihov otrov na tebe ne djeluje, da smireno nastaviš svojim Putem. Prema uzvišenom Cilju.

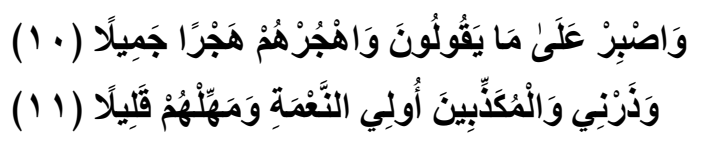

10. I otrpi ono što oni govore i izbjegavaj ih na prikladan način.

\section{A Mene ostavi i one koji te u laž ugone, koji raskošno žive, i daj im malo vremena.}

Sabur, taj veliki Božiji dar, će ti pomoći da vješto izbjegneš njihove zamke, provokacije na koje očekuju da reaguješ ishitreno, da svoje dostojanstvo pogaziš, da se pred njima poniziš, da postaneš isti kao oni. 
Neka te raskoš u kojoj žive ne obeshrabri. Samo trenutak tvog zadovoljstva, kada si na sedždi, Bogu blizu, i osjećaš tako jako Njegovu prisutnost, tu, s tobom, bliže ti od tvoje žile kucavice, vrjedniji je od svega što oni imaju. Osim toga, oni nisu ni svjesni da su svakog trena sve bliže i bliže bolnom iznenađenju koje ih očekuje. A misle da imaju vremena. I misle da uživaju. Jadnici.

Prepusti ih njihovom upornom bježanju od Istine. Svi su oni poput onog, iz Pejgamberovog vakta poznatog, Velid b. Mugire čija duša je prepoznala Riječ Božiju i priznala da je zadivljujuća, i Božija, ali nakon što su mu njegovi „dušebrižnici“ provokacijom „mozak isprali“, porekao je. Izazvali su otpor u njemu, tvrdeći kako se dodvorava Pejgamberu i ashabima radi neke svoje materijalne ili egzistencijalne koristi i udarili mu na ponos. Radi beskorisnog ponosa, ustvrdio je kako je Kur'an samo nekad davno ispričana priča, a ni sam $\mathrm{u}$ to nije vjerovao. ${ }^{5}$ Ponos mu je bio važniji od Istine. Takav je svaki Velid b. Mugire, u bilo kojem vaktu. Svi isto misle i isto tvrde.

Pusti ih Njemu!

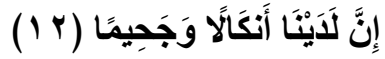

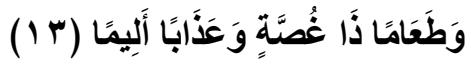

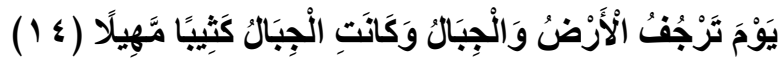

12. Bit će u Nas, doista, okova i ognja,

13. i jela koje u grlu zastaje, i patnje nesnosne,

14. na Dan kada se Zemlja i planine zatresu,

i planine - mehke pješčane dine budu.

Ti strpljivo slijedi staze Gospodara svoga i boj se Dana kada će strašni potres sve zahvatiti, kada će ljuta stijena mehka praška postati, a površina Zemlje odjednom potpuno ravnom ostati. Tog Dana one koji tebe smatraju nerazumnim, jer vjeruješ u Istinu, čekaju brojna bolna iznenađenja. Među njima Rabb izdvaja četiri:

\footnotetext{
${ }^{5}$ Predaju o tome od Ibn 'Abbasa bilježe El-Bejheki i El-Hakim. Navođena je i u: Tefsir Ibn Kesir, skraćeno izdanje (skratio Muhammed Nesib er-Rifa i), Sarajevo, 2002, str. 1446 .
} 
a. Okove. U zamjenu za dunjalučke stege kojima su vlastitu dušu okivali, a tjelesnim užicima ih nazivali, i vlastitoj duši branili da do čistoće dođe, dobit će vatrene obruče iz kojih izbavljenja nema.

b. Oganj. U zamjenu za vatrene strasti koje su im, na Dunjaluku, i tijelo i dušu sagarali, a domove im razarali, čeka ih Oganj koji jednako lahko u prah pretvara i ljudsko meso i ljuti kamen.

c. Jelo koje davi. U zamjenu za bezvrijedni ponos koji nisu mogli progutati i Bogu veličinu priznati, pa ponizno na sedždu pasti, imat će jelo koje će im u grlu zastajati i vječno ih daviti.

d. Patnja nesnosna. Kao nastavak paćenja vlastite duše na Dunjaluku, koju su lišavali istinskog užitka u Božijoj blizini, dobit će vječnu patnju, u kojoj im neće biti ni života ni smrti.

Bože Milosni, Ti nas zaštiti od patnje i Ovdje i Tamo, a i u Međuvremenu. I nas i naše najmilije, kojima si Ti drag i koji su Tebi dragi.

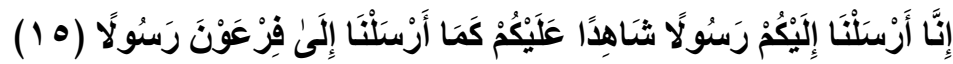

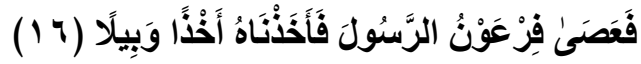

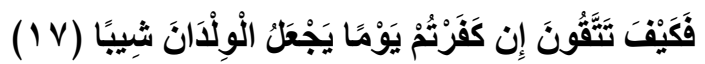

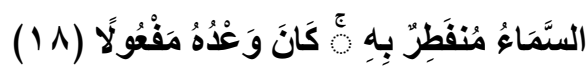

15. Mi smo vam zaista poslali Poslanika da bi svjedočio protiv vas isto onako kao što smo i Faraonu poslanika poslali,

16. ali Faraon nije poslušao poslanika, pa smo ga teškom kaznom kaznili.

17. Kako ćete se, ako ostanete nevjernici, sačuvati Dana koji će djecu sijedom učiniti?!

18. Nebo će se toga dana rascijepiti, i prijetnja će se Njegova ispuniti.

Pokušaj se sačuvati strahota tog Dana dok si još Ovdje. Nemoj praviti greške nekih ranije kojima je Bog Dragi Svoju milost slao po Svojim pejgamberima, a oni su je oholo odbijali. Teško onima koji se budu faraonski ponašali. Protiv njih će svjedočiti njihovi pejgamberi. A i oni sami će protiv sebe svjedočiti. Njihova oholost će se pred njima pojaviti i još jednom ih progutati svojim vatrenim grotlom. 
Nemoj dozvoliti da popustiš pred povremenim napadima slabosti. Ojačavaj duh noćnim ibadetima. O tvojoj snazi u Dinu će svjedočiti, osim noći, tvoj Pejgamber. Pomozi i drugima da budu jaki i ustrajni, kako bi i u njihovu korist Pejgamber svjedočio.

Teško onima protiv kojih budu svoju riječ kazali njihovi pejgamberi. Čeka ih strahota. Kada bi tu strahotu djeca vidjela, njihove dječije crnokose glavice bi dobile staračku, sijedu boju od straha. ${ }^{6}$

I ti bi osijedio istog momenta kada bi vidio kako se nebo cijepa, bezdan otvara, sve propada, a samo se prijetnja Rabba tvoga pojavljuje. Svarna i strašna.

Čuvaj se dok još možeš i imaš vremena! Rabbova milost ti ga je dala. Budi zahvalan!

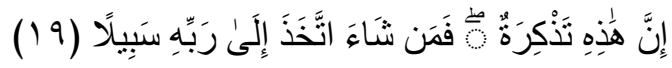

\section{9. "Ovo je, doista, pouka; i ko hoće, Put ka Gospodaru} svome prihvatit će!

Kada te je već Uzvišeni Rabb obradovao da čuješ Njegovu Riječ, da je u lijepom Mushafu tako mudro sabranu u rukama držiš, onda je poslušaj. Svaki dio Puta kojim te ona vodi pažljivo prelazi. Nemoj da ti promaknu neki važni momenti koji bi tvom putovanju dali veći kvalitet. I nemoj da drijemaš na putu. Tvoja jahalica bi te mogla vratiti nazad. Izgubljeno vrijeme, koje bi trošio dok budeš ponovo išao već pređenom trasom je nenadoknadivo.

Pouku uzmi i prenesi je dalje.

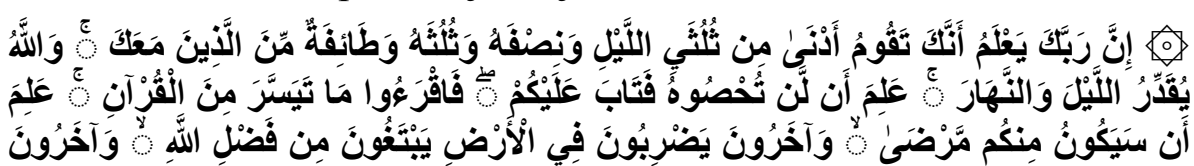

\footnotetext{
${ }^{6}$ Strahote agresije na Bosnu i Hercegovinu i genocida nad Bošnjačkim narodom su mnoge mlade ljude u starce pretvorile. Bediuzzeman Said Nursi strahote rata smatra jednim vidom dunjalučke realizacije ovog ajeta. On o strahotama Prvog svjetskog rata svjedoči: "I mada sebe još nisam ubrajao u starce, ipak onaj ko iskusi rat jeste starac, jer ratni dani, njihova grozota obijeli mladiće, kao da ih prožima jedna od tajni ajeti-i kerima: Dana koji će djecu sijedom učiniti. Iako sam bio blizu četrdesete, osjećao sam kao da sam u osamdesetim godinama." Vidi: Said Nursi, Odsjaji, (preveo Abdullah Smajić), Sarajevo, 2007. str. 446.
} 


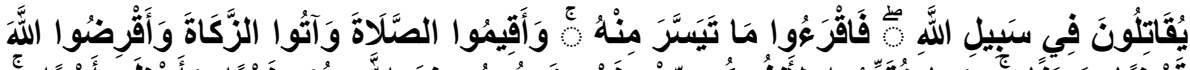

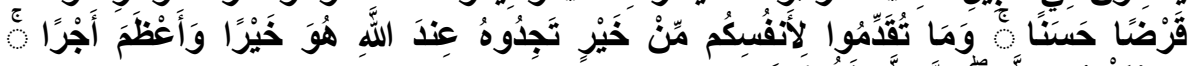

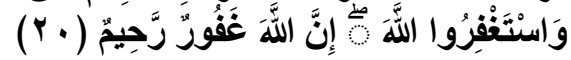

20. Gospodar tvoj sigurno zna da ti klanjajući bdiješ

manje od dvije trećine noći, polovinu njezinu,

ili trećinu njezinu,

a i skupina od onih koji su uz tebe.

Allah određuje dužinu noći i dana.

On zna da vi to nećete moći izdržati pa vam prašta,

a vi iz Kur'ana učite ono što je lahko.

On zna da će među vama biti bolesnih;

i onih koji će po svijetu putovati, i Allahove blagodati tražiti;

i onih koji će se na Allahovu putu boriti.

Pa učite iz njega ono što (vam) je lahko,

i namaz obavljate, i zekat dajite,

i Allahu lijep zajam dajte!

A dobro koje za sebe unaprijed date naći ćete kod Allaha još boljim i po nagradi većim.

I molite Allaha da vam oprosti, jer,

Allah prašta i milostiv je."

A pouka je i u tome što Uzvišeni ima obzira prema tebi i, iz milosti Svoje, ne zahtijeva da se, dok ibadetiš, mučiš. U različitim godišnjim dobima je dužina noći različita, kao i dnevne obaveze. Ti, kao i ljudi oko tebe, koji s tobom dijele iste dinske osjećaje, bavite se različitim djelatnostima. A ni zdravlje nije uvijek najbolje. Stoga, dobro procijeni koliko vremena ćeš provoditi u ibadetu, da ne bi u tome prešao mjeru i uskratio sebi mogućnost za druge, Bogu također drage, oblike iskazivanja zahvalnosti Njemu. 
Kad Kur'an učiš, u namazu i izvan njega, čini to s ljubavlju prema Onome čija je to Riječ. I s lahkoćom. Ono što najbolje znaš. I pažljivo. I polahko.

Kad klanjaš čini to sa zadovoljstvom, a ne s mukom.

Kada izdvajaš nešto od materijalnih darova od Boga ti datih, $i$ dijeliš ih s drugima, i to čini s osjećajem vedrine, a ne smrknuta čela $\mathrm{i}$ stisnuta srca. ${ }^{7}$

Kad sa užitkom ibadetiš to je onda znak da si na Putu s obje noge. To je, također, znak da je Uzvišeni s tobom i da te On vodi. Osjećati slast imana i slast ibadeta je Njegov dar onima koji Njemu posvećuju svoje vrijeme. I svoje srce.

\section{EL-MUDDESSIR / POKRIVENI (74)}

O, ti, koji u svom Hirau za Istinom tragaš, ti koji si, u dugim zimskim i kratkim ljetnim noćima, čitajući Riječ Božiju, stremio ka Njegovoj blizini, i uživao u njoj na sedždu spuštenog čela, nemoj se svojom osamom od drugih udaljiti. Ako si do sada bio umotan u svoju samoću, vrijeme je da bogatstvo koje si u njoj dobio s drugima velikodušno podijeliš.

Sjeti se da ni tvoj najveći učitelj među ljudima, Dika svih svjetova, Božiji miljenik Muhammed-pejgamber, nije mogao ostati skriven i pokriven, izdvojen i udaljen od drugih, kada se ono, zbog uzbuđenja i zaokupljenosti veličanstvenim prizorom Džibrilovog prirodnog lika, koji je horizont zaklanjao, i od zemlje do neba sezao, bio u svoj dom povukao i da ga pokriju zatražio. Ipak je morao ustati i druge upozoravati na greške koje čine, prema sebi i drugima, prema Bogu i svjetovima. ${ }^{8}$

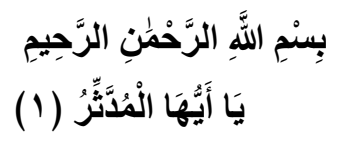

${ }^{7}$ Prenosi Haris b. Suvejda da mu je Abdullah kazivao: „Vjerovjesnik, s.a.v.s., je upitao: 'Kome je od vas imetak njegovog nasljednika draži od njegovog imetka?' 'Allahov Poslaniče', odgovorili su, 'nema nikog među nama da mu njegov imetak nije draži!' On reče: 'Doista je njegov imetak onaj kojeg podijeli, a imetak njegovog nasljednika onaj kojeg ostavi iza sebe.!'“ Vidi: Sahih el-Buhari, t. 4. str. 593.

${ }^{8}$ Vehbe ez-Zuhajli, Et-Tefsir el-vedžiz; Damask, 1994, str. 575. 


\section{(r) قُمْ فَأَنَذْز}

\section{U ime Allaha, Milostivog, Samilosnog!}

\section{O ti, pokriveni!}

\section{Ustani i opominji!}

Zato se i ti odreci svoje usamljenosti i pomozi ljudima, najprije onima koji su ti najmiliji, zatim ostalima u svom okruženju, da poput tebe, shvate da osim ovoga ima i Drugi svijet, da je najveća vrijednost i na jednom i na drugom, čvrsta vezanost za Stvoritelja svih svjetova i odanost Njemu. Tako ćeš bar malo osjetiti slast i važnost upoznavanja sa Objavom i njenog dijeljenja s drugima.

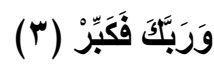

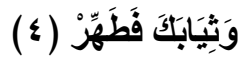

\section{I Gospodara svoga veličaj!}

\section{I haljine svoje očisti!}

Svugdje, gdje ti se prilika pruži, ističi koliko je veličanstven Rabb tvoj, koliko je milostiv i darežljiv, te kako je Njegovo vođstvo neophodno potrebno i onom čiji je koeficijent inteligencije nizak, kao i onome čiji je na, do sada, najvećoj izmjerenoj razini. On je najveći! On od tebe očekuje da sve što činiš činiš na najbolji način, pa i kada prenosiš drugima istinu o Njemu.

Ako želiš da i svojom vanjštinom i svojom unutrašnjošću budeš dostojan uloge veličanja Njegove Riječi, onda nastoj da si uvijek čist, pod abdestom, čiste odjeće i čistog srca. Odbacuj sa sebe, i izbacuj iz sebe, sve što može zasjeniti iskrenost tvog hizmeta Rabbu i njegovoj Riječi.

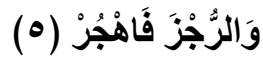

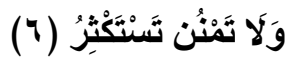

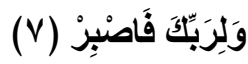

5. I kumīrā se kloni!

6. I ne prigovaraj držeći da je mnogo!

\section{I radi Gospodara svoga trpi!}


Tvoju čistoću, čistoću tvoje duše posebno, može ponajviše uprljati uticaj savremene idolatrije. Ne dozvoli da joj se dopadnu idoli kakvi su: vlast, bogatstvo, popularnost i njima slični, ma koliko šejtan nastojao da joj ih prikaže u najljepšoj mogućoj slici. Ako ti duša još nije dovoljno čvrsta, povećavaj joj snagu noćnim ibadetima.

Žrtvujući svoje vrijeme i snagu, a često i svoja materijalna dobra, u svrhu postizanja cilja - dijelenja Božije Riječi s drugim ljudima, nemoj očekivati da će ti se odmah vratiti više nego si uložio. To bi bio znak nedostatka strpljenja, a sabura ti u takvoj misiji treba ponajviše. Budi uvijek spreman da kroz svoj hizmet Kur'anu i Dinu podneseš i neprijatnosti koje ti mogu prirediti nevjerujući ljudi, kako bi umanjili rezultat tvojih pozitivnih nastojanja. Ti samo naprijed, i saburli. Ne daj se ometati. Svjestan budi u svakom momentu da je tvoj hizmet most do Božijeg zadovoljstva, do Rabbovog raziluka. Na Dan kada bude strašno, Njegov raziluk će ti biti najpotrebniji. Kao i sada.

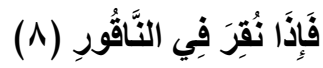

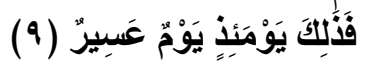

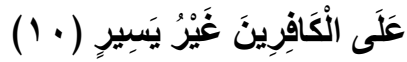

\section{A kada se u Rog puhne -}

\section{9. biće to naporan Dan}

\section{0. nevjernicima, neće biti lagahan.}

S radošću i nadom da će ti Dragi Rabb tvoj hizmet ukabuliti, bori se da Riječ Njegova nađe svoje mjesto u što više srca. I uporno to čini. Jer - nije mnogo ostalo do trenutka kada će se Rog oglasiti i cijeli Dunjaluk nestati. Sve živo će tada svoj život vratiti Onome koji im ga je darovao.

A kada se i po drugi put Rog oglasi, uspravit ćemo se iz kabura svojih, i mi i svi oni koji su prije ili poslije nas u njih spušteni, ili ih je prvi Rog zatekao kako po Zemlji hodaju, pa su bez života ostali. Kako će to strašan Dan biti. Posebno za one koji će biti svjesni da su taj Dan, dok su bili na Dunjaluku, tako uporno poricali i Riječ Božiju odbacivali, a ona se, eto, obistinjuje. 
Bit će to težak Dan. Pun neizvjesnosti i straha. Još davno, u Pejgamberovom vaktu, on sam, Dika svih svjetova, imao je brigu kako ćemo taj Dan dočekati. U kakvom stanju? Kada bi o tome razmišljao, nemir bi ga hvatao. Kada bi ga umirivali, odgovarao im je: "Kako da budem spokojan, a melek, koji je zadužen za Rog, već ga je uzeo u usta i pognuo čelo čekajući kada će mu biti naređeno da puhne u njega..." Još tada je to bilo očekivano. A mi, što smo od Pejgamberova vakta dalje, sve smo tom Danu bliže. Budi toga sam svjestan a i drugima pokušaj prenijeti istinu o isteku vakta cijelom Dunjaluku i svima nama.

Pričaj, kome god stigneš, i o slučaju kada je jedan kadija Basre, klanjajući sabah učio ovu suru, pa kada je stigao do ajetā: A kada se u rog puhne - bit će to naporan Dan; nevjernicima neće biti lagahan... zahroptao je i na zemlju mrtav pao. ${ }^{10}$ Neka i njega i nas Allah Dragi Svojim rahmetom pospe. Eh, kako smo mi daleko od tog nivoa, od tako jakog osjećaja straha i odgovornosti.

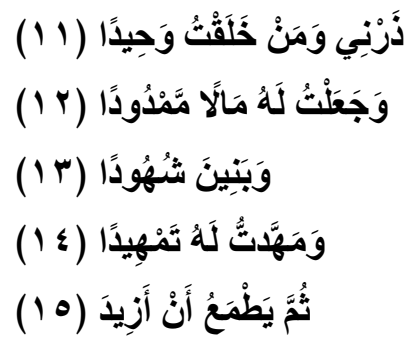

11. Meni ostavi onoga koga sam Ja stvorio samog (bez ikoga i ičega)

\section{2. a onda mu i bogatstvo ogromno dao,}

13. i sinove koji su (svugdje) s njim,

\section{4. i čast i ugled mu pružio -}

\section{5. a on, nakon svega toga, žudi da mu (sve to) još uvećam!}

Od nas se očekuje da, poput našeg Pejgambera, budemo zabrinuti za svoje stanje i stanje nama najmilijih, a što se tiče onih koji za strahote Dana Ustajanja uopće ne mare, njih prepusti njihovom Stvoritelju i Gospodaru. On svakog takvog, kakav je u Pejgamberovo

\footnotetext{
${ }^{9}$ Vidi: Tefsir Ibn Kesir, str. 1446.

${ }^{10}$ Vidi: Isto, str. 1446. 
vrijeme bio i Velid b. Mugire, podsjeća da ih je upravo On, a ne neko drugi, stvorio bez igdje ičega, same; da im je dao sve što imaju, te da su njihove duše tako nezahvalne i nezasite da uopće ne žele da zahvalnost pokažu, nego neprestano žude za više, govoreći: „Ima li još? Ima li još? ‘11

Ta njihova neutoljena glad za Dunjalukom ne dozvoljava im da mirno promisle o sebi i svom položaju na ovom Svijetu, svojoj ulozi i zadacima, svom odnosu prema sebi i drugima. Njegov lični interes je uvijek iznad svega. On hoće uvijek sebi, a za druge ne mari. Važan je njegov ugled i položaj u društvu, njegovo imovinsko stanje i porodični status, a drugi nisu bitni. U tvom okruženju ima mnogo takvih ljudi. Nemoj da te oni obeshrabre. Njihovi sudovi o Vjeri i Božijoj Riječi nisu objektivni i ne mogu biti mjerilo istine.

Zar se ti ljudi mogu nadati da će uspjeti ostvariti svoje želje na Dunjaluku, čak i kada ne bismo uopće govorili o Ahiretu? Zar jedan takav prkosnik može očekivati da njegov prkos i uporno odbijanje da posluša šta mu poručuju toliki ajeti Knjige Božije, te ajeti u njemu i oko njega, kao rezultat donesu sreću? Nikada! Ni prije njegovog smrtnog časa, ni poslije njega.

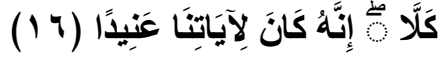

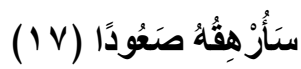

\section{Nikako! On, doista, prkosi ajetima Našim -}

\section{7. a naprtiću Ja njemu teškoće,}

Poslušaj kako takvome Uzvišeni i Moćni, Silni i Snažni prijeti teškom patnjom nakon što napusti Dunjaluk. Koliko god da mu Ovdje izgleda da uživa i naslađuje se, sve mu to kasnije postane samo postepeno približavanje strašnoj, a vječnoj patnji. Zaokupljen svojim pohlepnim težnjama i svojim sebičnim nastojanjima da sam ima što više svega što može imati, on ni na Dunjaluku ne primjećuje da ostaje sam, prezren od mnogih, odbačen često i od sebi najbližih. Zar to nije već patnja? Još Ovdje.

\footnotetext{
${ }^{11}$ Ibn 'Abbas tvrdi da je Velid b. Mugire imao oko devet hiljada miskala srebra. Vidi: Ebu Tahir b. Ja'kub el-Fejruzabadi, Tenvir el-mikbas min tefsir Ibn 'Abbas, Damask, 1918, str. 491.
} 
A kakva ga tek patnja čeka Tamo. Naš dragi Pejgamber je spominjao da takve, u Džehennemu, čeka jedno brdo koje se zove Sa ud, brdo od vatre, na koje će se on, nevjernik, penjati po sedamdeset godina, a kada se uspne na njegov vrh biti će srtmoglavljen u njegovo podnožje, da bi se ponovo uspinjao, i tako vječno... ${ }^{12}$ A brdo vatreno. Sačuvaj nas Bože! Dobro se čuvaj oholosti i uobraženosti! Na njih upozoravaj i sve one do kojih ti je stalo!

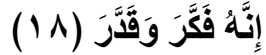

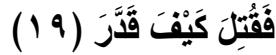

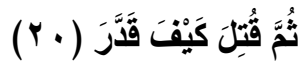

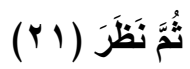

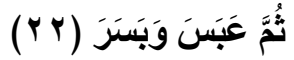

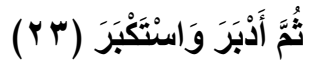

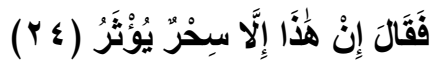

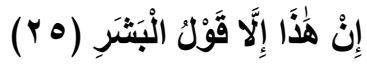

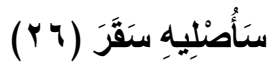

18. On je smišljao i računao -

19. i, proklet bio, kako je proračunao!

20. I još jednom, proklet bio, kako je proračunao! -

21. Zatim je pogledao,

22. pa se onda smrknuo i namrštio

23. i potom se okrenuo i uzoholio,

24. i rekao: "Ovo nije ništa drugo do vradžbina koja se nasljeđuje,

25. ovo su samo čovjekove riječi!"

\section{U Sekar ću Ja njega baciti.}

Negdje duboko u sebi, ti ljudi, a tako je bilo i sa spomenutim Velid b. Mugirom, prihvataju da je Riječ koju je od Boga nama prenio

\footnotetext{
${ }^{12}$ Vidi: Isto, str. 1447.
} 
Njegov Pejgamber, uistinu, Riječ Božija i da je, kao takvu, treba prihvatiti i poslušati, ali im njihov nām, njihov ponos i prkos, ne dozvoljavaju da to javno priznaju. Kao da se boje da će, priznavanjem i prihvatanjem Istine, biti oboren njihov ugled u očima protivnika Istinske Vjere; da će se time poniziti; da će neko tamo pomisliti kako se oni dodvoravaju vjerujućim ljudima, želeći postići neki svoj materijalni interes, i slično. Iz tih i takvih razloga oni će radije Božiju Riječ smatrati nekom sumnjivom vradžbinom koju ljudi uče jedni od drugih već stoljećima, nego priznati da je Istina od Boga objavljena. ${ }^{13}$

Kada već poriču i javno to čine, onda svom poricanju žele dati ozbiljan ton. Izjave daju glumeći intelektualnost i promišljenost, mudrost i umnost, a sve to, ustvari, pokriva samo i jedino njihovu oholost. U tvom nastojanju da Božija Riječ nađe svoje mjesto u tvom okruženju, naići ćeš na mnogo takvih. Njihov otpor tvom hizmetu Božijoj Knjizi ne umanjuje vrijednost nagrade koja te za hizmet čeka, a šta čeka njega? Zbog svog inata je, eto, proklet još na ovom Svijetu, a Sekar je daleko teži od prokletstva. I vječna je patnja. Sačuvaj nas Bože!

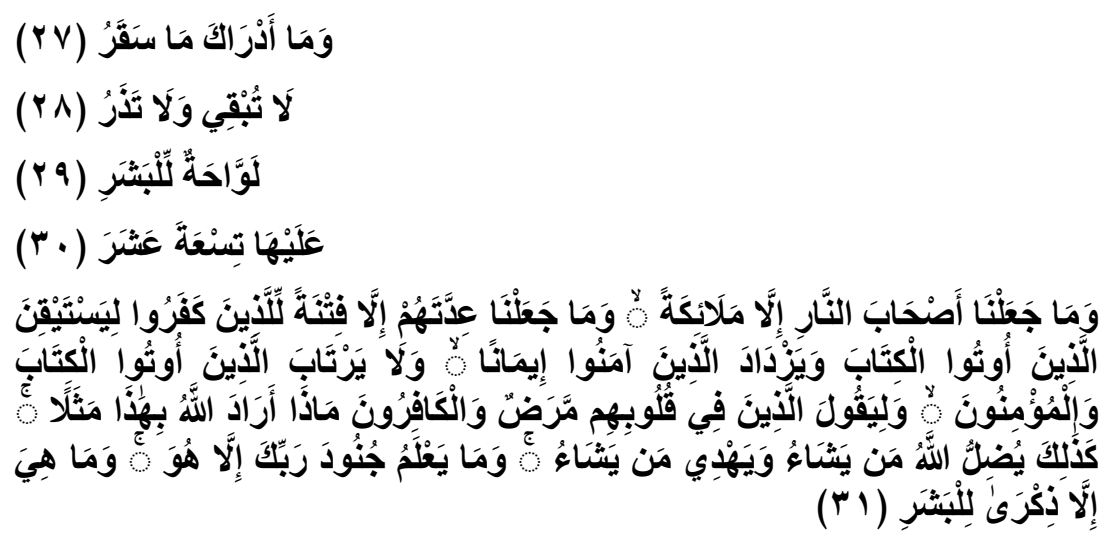

27. A znaš li ti šta je Sekar?

28. Ništa on neće poštedjeti,

29. kože će crnim učiniti,

30. nad njim su devetnaesterica.

13 Vidi povod objavljivanju ovih ajeta u: Jusuf Ramić, Povodi objave Kur'ana, Sarajevo, 1984, str. 230-231. 


\section{Mi smo čuvarima Vatre meleke postavili}

i odredili broj njihov kao iskušenje onima koji ne vjeruju,

da se oni kojima je Knjiga data uvjere,

i da se onima koji vjeruju vjerovanje učvrsti,

i da oni kojima je Knjiga data i oni koji su vjernici ne sumnjaju,

i da oni čija su srca bolesna i oni koji su nevjernici - kažu:

"Šta je Allah htio ovim primjerom?"

Tako Allah ostavlja u zabludi onoga koga hoće,

i na Pravi put ukazuje onome kome hoće.

A vojske Gospodara tvoga samo On zna.

\section{Sekar je ljudima samo opomena.}

Vatra oholosti spaljuje pozitivne osobine i od njih ne ostaje ništa. Samo jedna velika praznina i mrtvilo. Baciti se u ponor oholosti, znači izvršiti duhovno samoubistvo. I nije riječ o padu koji ima kraj. To je niz padova koji iznova jednu po jednu vrijednost u prkosniku obara. I tako u nedogled. Vječno prokletstvo padanja. Kako je to teška kazna, a onaj ko je u toj vatri misli da uživa. Kolika je to zabluda i samoobmana!

Šta je stvarna Vatra, tek će Tamo vidjeti. To je nepoštedni Plamen koji nikada nije čuo za riječ milost. I pokoran je svom Gospodaru, kao i koža prkosnika koju će spaljivati. A koži je naređeno da, čim izgori opet u svoje prvobitno stanje dođe, kako bi iznova gorjela i boljela. Vječna bol. Kako je oholost teška patnja. Bježi od nje!

Onako kako prkosniku Ovdje šejtan čuva leđa, dok on polahko, a sigurno, pada sve niže i niže, tamo će nad njim i njegovom Vatrom bdjeti meleki azaba, strogi i nemilosrdni, kao i Vatra koju čuvaju i neće mu dozvoliti da iz nje izađe. Niko od njih devetnaest to neće dozvoliti. Sačuvaj nas Bože!

Neka znaš da ni Sekar ni njegova strahota i žestina, kao ni svih devetnaest meleka koji ga čuvaju, za prkosnika koji padne na samo 
dno ponora svoje oholosti nisu prepreka da propada sve dublje, Vatri sve bliže. U njegovoj glavi je ista ona pomisao, tako drska i ohola, koju je imao i faraon Pejgamberova vakta, Ebu Džehl, da vojske Ovog svijeta mogu svojom brojnošću i snagom savladati silinu meleka azaba. ${ }^{14}$ Vara se isto onako kako se i Ebu Džehl uvijek varao kada je Pejgambera i Istinski Din osuđivao, bahato se ponašajući.

Tebi, koji istinu u svom Hirau tražišs, neka i Sekar i njegovi čuvari budu opomena. Čuvaj se oholih i njihove oholosti. Ti i oni koji su ti dragi.

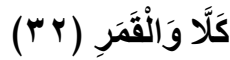
وَاللَّيَّل إِذْ أَدْبَرَ (بr)

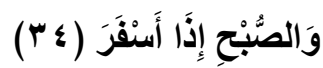

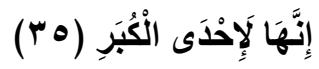

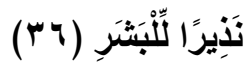

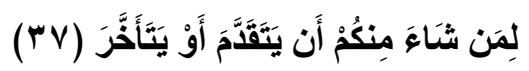
32. Ne! ${ }^{15}$ Tako Mi Mjeseca!
33. I tako Mi noći kada mine,

34. i zore kada svane -

35. on (Sekar) je, zaista, najveća nevolja.

36. Ljudima je opomena -

\section{7. onome između vas koji želi činiti dobro}

\section{ili onome koji ne želi!}

Znaj, Allah ti poručuje, da se melekima azaba niko ne može suprotstaviti, i ozbiljno to shvati. Ti i svi do kojih ti je posebno stalo.

\footnotetext{
14 Ibn-Ishak i Katade vele: Jednog dana je Ebu-Džehl izjavio: "O Kurejšije, Muhammed tvrdi da je vojska Allahova koja će vas kažnjavati u Vatri njih devetnaest, a vas ljudi ima više, i stotinu vas će onesposobiti, pobijediti, savladati jednog njihovog!", pa je Allah objavio: A za čuvare Vatre Mi smo samo meleke postavili... Vidi: Ez-Zuhajli, Et-Tefsir el-vedžiz, str. 577.

15 „Ne (kella)!, je ovdje radi opomene i upozorenja, te prijekora onome ko tvrdi da se može suprotstaviti čuvarima Vatre. Ovo Ne! je potkrijepljeno zakletvom.“, tvrdi Zuhajli. Vidi: Isto, str. 577.
} 
Da je to tako Uzvišeni se, vidiš i sam, Mjesecom zaklinje. A i noć i zoru kao objekte Svog zaklinjanja koristi kako bi ti ukazao da je istina o Sekaru, koju ti u Svojoj Knjizi iznosi, doista blagovremeno upozorenje. Prije nego bude prekasno. On je upozorenje ne samo tebi, koji želiš i nastojiš što više dobra učiniti, radi Božijeg raziluka, nego i svima onima koji se takmiče ko će više zla učiniti i time se ponose. Teško njima! Sačuvaj nas Bože!

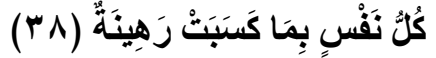

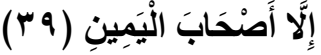

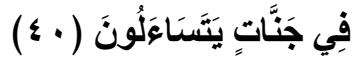

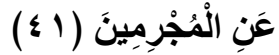

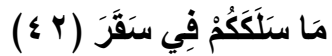

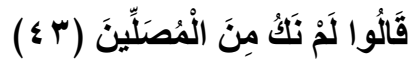

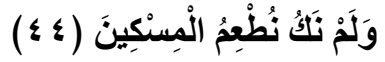

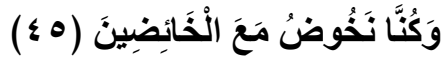

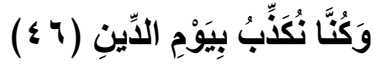

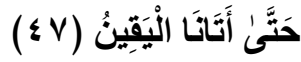

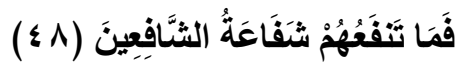

38. Svaki čovjek je zalog za ono što je uradio.

39. Osim sretnīkā.

40. Oni će se u džennetskim baščama raspitivati

41. o nevjernicima:

42. "Šta vas je u Sekar ${ }^{16}$ dovelo?"

43. "Nismo" - reći će - "bili od onih koji su namaz klanjali

44. i od onih koji su siromahe hranili,

45. i u besposlice smo se sa besposlenjacima upuštali,

\footnotetext{
${ }^{16}$ Sekar je jedno od “imena datih u Kur'anu pojmu patnje na onom svijetu koju čovjek navlači na sebe griješenjem i namjernim ostajanjem slijepim i gluhim, na ovom svijetu, prema duhovnim istinama..." Vidi: Muhammed Asad, Poruka Kur'ana, str. 928.
} 


\section{6. i Sudnji dan smo poricali,}

\section{7. sve dok nam smrt nije došla."}

\section{Njima posredovanje posrednika neće biti od koristi.}

Dok si Ovdje, ne možeš znati zasigurno svoj status Tamo, ali možeš željeti i nadati se, i raditi na realizaciji svojih želja i nadanja, čineći dobro i pokoravajući se željama svog Rabba.

Daj Bože da i ti i svi oni do kojih ti je posebno stalo, stignete, zajedno s nama, i svim vjerujućim ljudima, na stepen sretnika, onih koji će imati čast da im knjiga njihovih djela bude spuštena u njihovu desnu ruku. Kako će to samo sretan trenutak biti. Duša će od sreće zasjati. Njen nur će joj osvijetliti sve što dalje bude morala proći. Zajedno sa drugima, koje je ista sreća dotakla, razgovarat će o onima kojima je baš ta sreća nuđena na Dunjaluku, a oni nisu vjerovali da takvo nešto uopće postoji. Njihov domet je bio sreća na Dunjaluku. Ako su je uistinu imali. Ako nije bio samo privid sreće, a jeste.

A kada takvi nesretnici, Tamo budu upitani zbog čega su se našli u strahotama Sekara, odgovorit će, posramljeni i drhtavo, kako nisu vjerovali ni tebi ni drugima koji su im o Sekaru govorili, ili iz Kur'ana čitali; kako nisu prihvatali da im je u namazu i ponizno spuštenom čelu pred Gospodarom svjetova spas; kako su odbijali povjerovati da velikodušno i od srca spušteni novčić u ruku siromahu može biti presudan na Dan vaganja djela; kako su, sve do časa napuštanja Dunjaluka, vrijeme trošili u igru i zabavu, u naslađivanja dunjalučkim poslasticama... kada bi se za njih tada založili i meleki, i pejgamberi, i dobri, čak im ni to ne bi pomoglo.

Kako će to biti tužna priča. Sačuvaj nas Bože! A eto, ta se istina nudi sada, tebi i drugima. Kao upozorenje. Na vrijeme. Da ne pogriješišs.

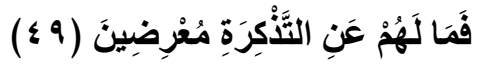

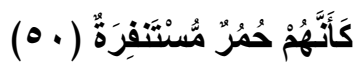

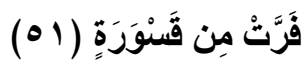

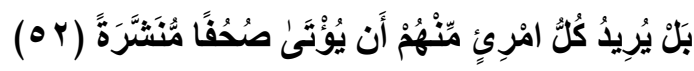

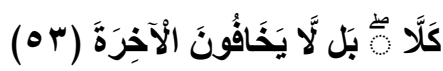




\section{Pa zašto oni pouku izbjegavaju,}

\section{0. kao da su divlji magarci preplašeni}

\section{1. koji od onih koji ih progone bježe?}

\section{rašireni. ${ }^{17}$ \\ 52. Da! Svaki čovjek bi od njih htio da mu se daju listovi}

\section{Nikada, jer oni se Onoga svijeta ne plaše!}

Budi sretan što pripadaš onima kojima se Uzvišeni smilovao otvorivši im srca prema Svojoj Uputi, i zahvaljuj Mu na tome. Neka ti stanje onih iz tvog okruženja čija su srca tvrda poput kamena i još tvrđa, budu primjer kako izgleda srce koje nije oplemenjeno Objavom. Takvo srce bježi od opomene, pa i od prijetnje Sekarom, isto onako kako bježi divlji magarac, kada ga potjeraju tragači. Što je divlji, pa još i magarac.

A, ustvari, se tu ne radi o bježanju nego o izbjegavanju i odgađanju. Željeli bi izbjeći obaveze koje od njih traži Din, i odgoditi trenutak istine $\mathrm{i}$ odgovornosti. Čak i kad bi im neko donio pred njih, ili kako su neki tražili, ${ }^{18}$ stavio im pod jastuk na kojem spavaju, listove na kojima su ispisana sva njihova djela, većinom ružna, i presuda da ih zbog toga čeka nesretni trenutak spuštanja tih listova u njihovu lijevu ruku, a poslije Sekar, ni ta ih presuda napismeno ne bi uvjerila i od njihovog inada izbavila. Jer - oni se Onog svijeta uopće ne boje. Ni onoga što ih Tamo čeka. Jer, ne vjeruju.

Čuvaj se svega što te može približiti tako ružnom stanju duše i moli Svemogućeg da te čuva tebe i sve one do kojih ti je stalo.

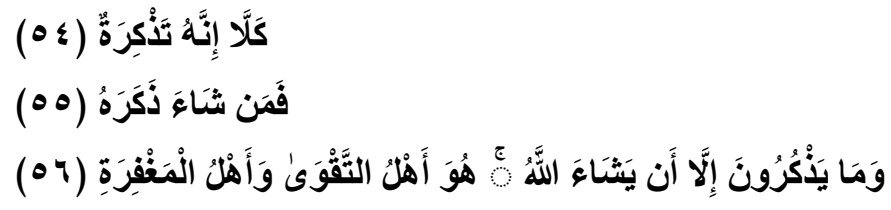

54. Uistinu! Kur'an je pouka,

\footnotetext{
17 Ajet ukazuje na krajnji stepen njihove arogancije ili lažnog ponosa. Vidi: Muhammed Asad, Poruka Kur'ana, str. 930.

18 Es-Sudi je rekao: "Ako Muhammed istinu govori, neka učini da se pod glavom svakog od nas nađe sahifa na kojoj će biti napisano za njega oslobođenje i zaštita od Vatre...", pa je objavljen ovaj ajet. Vidi: Ez-Zuhajli, Et-Tefsir el-vedžiz, str. 578.
} 


\section{5. i ko hoće, na umu će ga imati.}

\section{A na umu će ga imati samo ako Allah bude htio.}

\section{On je jedini dostojan da Ga se boje}

\section{i On jedini prašta. ${ }^{19}$}

Želje nevjernika da izbjegnu vječnu patnju se neće ostvariti. Nikada! Zato se ti čvrsto drži Kur'ana kao pouke i njegove istine dijeli s drugima. Druži se s Kur'anom svakodnevno, a njegove smjernice živi. Neka ti je uvijek na umu da ništa ne možeš učiniti bez Božije volje, pa ponizno, i često, Njega moli da te vodi stazama kur'anskim ukrasima okićenim.

I nemoj se bojati poteškoća. Boji se Njegovog nezadovoljstva i čuvaj se da Ga ne naljutiš. Ako pogriješiš, moli Ga da ti oprosti. On voli praštati. I voli one koji Ga mole. Ne odvajaj se od njih.

\section{Zaključak}

Ovakav način crpljenja poruka iz teksta Božije Upute nije naročitio složen. Potrebno je, kako smo vidjeli, učiniti nekoliko praktičnih koraka:

- Prihvatiti činjenicu da kur'anska Poruka nije stvarnost izvan naše, nego da se tiče svih nas skupa i svakog od nas pojedinačno, sada i ovdje;

- Pokazati volju i spremnost da svoj životni put definišemo spram smjernica koje nam Kur'an nudi;

- Čitajući Kur'an istovremeno analizirati svoje vrijeme i svoje okruženje, našu realnost, i u skladu s tim preuzimati kur'anska rješenja za dileme i probleme svog vremena;

- Nakon kušanja ispravnosti pratičnog življenja Kur'ana ponuditi svoje iskustvo drugima.

\footnotetext{
${ }^{19}$ Od Enesa b. Malika prenosi se da je rekao: "Allahov Poslanik, s.a.v.s., je proučio ovaj ajet: 'On je jedini dostojan da Ga se boje i On jedini prašta', i rekao: 'Vaš Gospodar veli: 'Ja sam dostojan da Me se bojite i da se pored Mene ne izmišlja božanstvo; ko se bude bojao da pored Mene izmišlja drugo božanstvo, zaslužit će da mu oprostim."' Hadis bilježe Ahmed i drugi. Vidi: Tefsir Ibn Kesir, str. 1449.
} 
Pri tome valja uvijek biti svjestan da je svo znanje u Najvećeg Znalca, Izvora svakog znanja, pa Njega moliti da nas, dok tragamo za smislovima Njegove Riječi, Svojom milošću vodi Ispravnim Stazama do ispravnih ciljeva.

\section{Literatura:}

1. Kur'an s prevodom, (preveo Besim Korkut), Sarajevo, 1989.

2. Kur'an s prijevodom na bosanski jezik, (preveo Esad Duraković), Sarajevo, 2004.

3. Kur'an sa prijevodom na bosanski jezik, (preveo Enes Karić), Sarajevo, 1995.

4. Tefsir Ibn Kesir, skraćeno izdanje (skratio Muhammed Nesib er-Rifa'i), Sarajevo, 2002.

5. Ez-Zuhajli, Vehbe; Et-Tefsir el-vedžiz, Damask, 1994.

6. El-Fejruzabadi, Ebu Tahir b. Ja'kub, Tenvir el-mikbas min tefsir Ibn 'Abbas, Damask, 1918.

7. Asad, Muhammed, Poruka Kur'ana, (preveo Hilmo Ćerimović), Sarajevo, 2004.

8. El-Buhari, Muhammed b. Ismail, Sahihu-l-Buhari, (preveo Hasan Škapur i grupa prevodilaca), Sarajevo, 2008.

9. Ramić, Jusuf, Povodi objave Kur'ana, Sarajevo, 1984.

10. Nursi, Said, Odsjaji, (preveo Abdullah Smajić), Sarajevo, 2007.

11. Ramadan,Tarik, Stopama Božijeg poslanika, Sarajevo, 2010.

12. Duraković, Esad, "Paralelizmi u al-Fatihi“, Takvim za 2008, Sarajevo, 2007. 
Sead Seljubac, Ph D

\section{HOW TO HEAR THE WORD OF GOD}

\section{SUMMARY}

This paper is an attempt to offer a way of understanding of the contents of the Qur'an in the way which gives priority to listening over reading. If the reader opens his heart to listen to the Word of God as directed directly to him, he will find many beautiful guidelines to change his life in a positive direction. And with every verse he shall be one step closer to obtaining the God's pleasure. Is not that the ultimate goal of every Muslim, sincerely committed to the dear God?

Keywords: the Word of Gid, the closeness to God, the pleasure of God 
الدكتور سآد سيلوباتس

\section{كيف نستمع إلى كلام الله \\ خلاصية البحث}

هذا البحث هو محاولة لتقديم طريقة لفهم محتوى القرآن عن طريق الاستماع

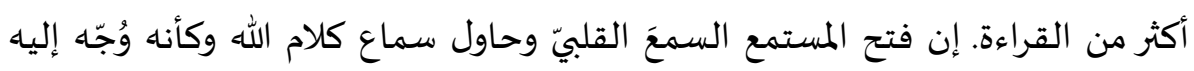

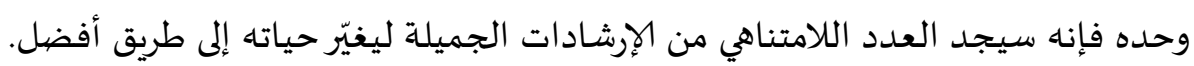

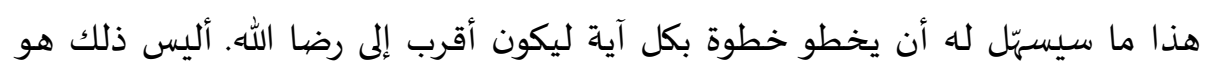
القصد النهائي لكل مسلم أخلص دينه لله العزيز.

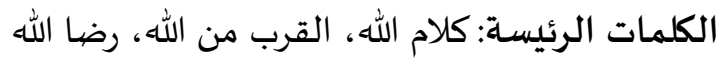

